\title{
Relevance Theory as an approach to interpreting the Bible for children: The Lucan version of the Lord's Prayer as a test case
}

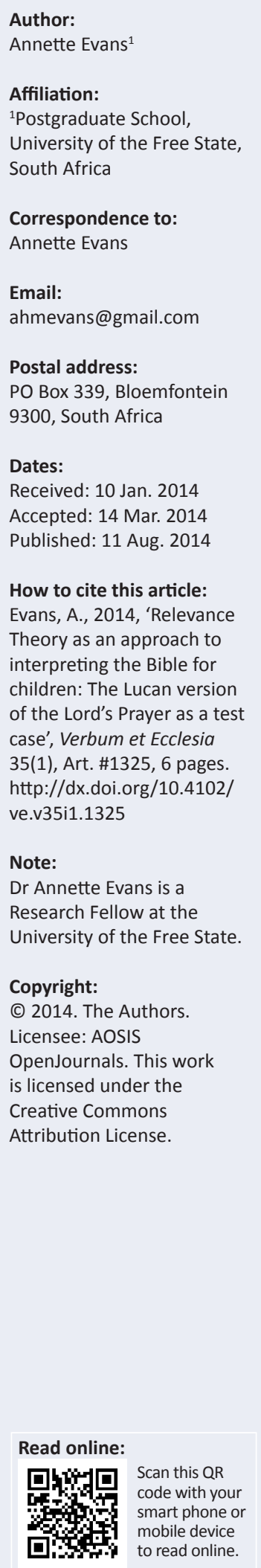

Recent research has demonstrated that children are sensitive to the underlying causal structure of the world and seek to form new causal representations at a much earlier age than had previously been supposed. Modern scientific understanding of the evolution of life conflicts with the biblical representation of earth as the centre of the world, and of human beings as the imago Dei. Consequently, young children frequently experience cognitive dissonance when exposed to biblical texts. Two previous pilot studies utilising specifically designed illustrated booklets demonstrated that children respond more readily to a text that is relevant to their own cultural context. This article tests the possibility of presenting a universally relevant biblical text (Lk 11:2b-4) to young children in a form that does not conflict with modern science and takes aspects of recent research on child psychology into account.

Intradisciplinary and/or interdisciplinary implications: In our postmodern cultural context children tend to experience cognitive dissonance when exposed to biblical texts, and consequently lose interest. This article proposes that by presenting the biblical content in accordance with Relevance Theory, and in coherence with recent scientific explanatory theories, the interest of the children may be sustained.

\section{Introduction}

Ruth Bottigheimer (1996:218), in her ground-breaking study of children's Bibles through the ages observed that children's Bibles have tended to mingle sacred text with secular values, and that children's Bibles changed as cultural norms changed. Samuel Heilman (1992:225) stated it baldly: children's Bibles are 'pretexts for passing along values'. This principle still applies, but in the shift from modernity to postmodernity cross-generational discontinuity is significantly heightened because young people are imbued with a vastly different set of cultural assumptions than those of their parents (see Jones \& Creasy-Dean 2006). The stimulus for this article was the realisation that the consequences of children's exposure to the Bible in a postmodern world need to be researched. For the purposes of this study 'postmodernism' is understood according to Millard Erickson's definition, that is, the objectivity of knowledge is denied, progress is rejected, truth is known through other channels than reason, for example intuition, and truth is defined by and for the community (see Erickson 1998:13-20).

The Bible takes it for granted that God created the world, but after the Copernican revolution the traditional Judaic-Christian world view that the earth and humans were the centre of a hierarchical cosmos stretching up to the perfect heavens' had to be reconsidered (Harrison 2007:7). In today's context of space travel even heaven needs to be redefined - it is no longer 'up there'. ${ }^{1}$ Modern scientific knowledge and globalism have made little impression on the customary approach to the presentation of Christianity to young children. Neither cosmology nor the science of evolution can take any position on the existence of God, but if we are to avoid cognitive dissonance in the youth, Christianity has to be presented in coherence with our current scientific context. ${ }^{2}$

The versions of Luke 11:2-4b used in this study reflect the significant shift towards discourseoriented principles of Bible translation whereby attention is paid to biblical exegesis, to the text itself, and to the reader: 'It is an axiom of modern translation practice that meaning is more important than form' (Pattemore 2007:236-237). Yet, not only does the reader need help in 'bridging the temporal and cultural gap between the biblical period and today' (Pattemore

1.See also Evans (2009:318). Lansdown's (1995:19) observation was noted that when informing children about a loved one's death, one should not assume that 'gone to heaven' is a satisfactory answer - it may raise many problems which would need some time to unravel.

2.For instance, Gold (2004:94-97) points out that a new understanding of the Bible has to be implemented amongst the lay public there has to be acceptance of the implications of the basic historicist findings established in the past 200 years. 
2007:236), but the meaning of the form of the text needs to be understood and retained. ${ }^{3}$

Intellectualist scholars in the anthropology of religion maintain that religion is primarily concerned with providing explanatory theories, and children too, are constantly trying to make sense of their world. Alison Gopnik has demonstrated that children are sensitive to the underlying causal structure of the world and seek to form new causal representations at a much earlier age than had previously been supposed (Gopnik 2000:302, 304). Even in the context of religion, the postmodern child has to be given information in a relevant form to incorporate (selectively) into his or her own 'causal map'. The 'everyday thinking and learning' of the postmodern child must be respected even when evangelising children. The message must be relevant to the child's 'here and now'. ${ }^{5}$

One obstacle to such Bible translation is that in general, the Christian establishment tends to regard the predominantly secular environment as threatening to the ideal of purity and integrity, often resisting any revision of the tradition (Mitchell 1996:271-277, esp. 273). The results of a recent study revealed that some parents are unsure about the mention of scientific facts in a biblically based book for young children, and that they seek biblical references (Evans forthcoming).

\section{Research questions, assumptions and methodology}

The foundational assumption of this pilot study is that Jesus was sent by God, the generator of all life (Father), to reveal God's care and love for the world, to the world. ${ }^{6}$ The main research question is, what aspect of evangelism would be relevant to a young child, and indeed, to what degree is interaction with a biblical text possible for a 5-10-year-old child growing up in a postmodern world? This study assumes that it is the practice of prayer that is relevant to young children, and that prayer is a basic form of worship and service of God in which even young children can participate. The methodological aim was to assess qualitatively how such a text operates within the minds of a culturally diverse group of young children between the ages of five and ten. In the past, school children have traditionally been made to learn Matthew's version of the Lord's Prayer by rote, sometimes with little understanding of the significance of the words of the prayer. In terms of the modernist question 'where is heaven?' the Lucan version of the Lord's Prayer (Lk 11:2-4b),

3 .In the booklet used in this field study, an inclusio type of form has been used to facilitate the conveying of what has been considered to be particularly relevant to young children.

4.Gopnik (2000) has shown that 'even very young children are deeply engaged in such profoundly cognitive work as hypothesis testing and causal inference'. See also Gopnik (2012:1626).

5.Referring to the beginning of a child's 'dance with God', Ratcliff (2004:11-12) perceives the process to begin when the child hears names for God and also the language of faith, but he warns that the dance can die: 'parents may unknowingly stifle the music, and the church may put the dance into a rigid box with fixed doctrine that may kill the dance.'

6.'The incarnation of God in Jesus Christ is at the base of all theology of mission (Sanchez-Cetina 2007:389). The conventional introduction of the Bible to young children by way of Adam and Eve and 'original sin' is avoided for reasons argued by Evans (2012:84-99) which does not refer to heaven at all, was selected because it seems to be pared to the bare bones of universal religious relevance. ${ }^{7}$

This qualitative pilot study presents the text in the form of an illustrated booklet with the text in isiXhosa, Afrikaans and English. In considering the question of what factors could enhance a young child's reception of a biblical text, Relevance Theory (RT) was selected as a methodological approach, thus in designing the booklet insights from RT were applied as far as possible. RT is an experimentally testable cognitive psychological theory. It treats utterance interpretation as a cognitive process, but Wilson and Sperber (2004) explain that:

it does not provide an absolute measure of mental effort or cognitive effect, and it does not assume that such a measure is available to the spontaneous workings of the mind. (p. 631) $)^{8}$

However, like other psychological theories it has testable consequences; for example, it is open to confirmation, disconfirmation or fine-tuning in the light of experimental evidence.

\section{Relevance Theory}

The following explanation of RT is mainly a paraphrase of a chapter by Dierdre Wilson, linguist, and Dan Sperber, cognitive sociologist (2004). In their initial presentation of RT in 2004 they attempted to provide a psychologically realistic account of communication. They attempted to work out in detail the claim that an essential feature of most human communication, whether verbal or non-verbal, is the expression and recognition of intentions. The relevancetheoretic account is based on the claim that utterances automatically create expectations which guide the hearer towards the speaker's meaning. Wilson and Sperber aimed to explain in cognitively realistic terms what these expectations of relevance amount to, and how they might contribute to an empirically plausible account of comprehension (Wilson \& Sperber 2004:607-632). RT is based on two principles: a 'cognitive principle' that human cognition is geared to the maximisation of relevance, and a 'communicative principle' which assumes that utterances create expectations of optimal relevance. Maximum relevance will result from the least effort expended in understanding. Thus, in relevance-theoretic terms, other things being equal, what makes it possible for the hearer to recognise the speaker's informative intention

\footnotetext{
7 Kaplan (1979) points out that prayer is a mechanism for transition from physical to spiritual consciousness. Biblical scholars have demonstrated that the Lord's Prayer is related to Jewish prayer, especially the Quaddish (81a, Babylonian), or some precursor of it. Cf. Isaiah 63:16: 'For you are our Father ... you, O LORD, are our Father' (the concept of God as a true Israelite father was already established with 1 st century Judaism). Also see 1 Chronicles 29:10b (King David's prayer); Proverbs $30: 8 \mathrm{~b}$ ('Feed me with the food that is needful for me'); Greek Sirach 28:2 (original Hebrew written 226-195 BC, translated 132-116 BC 'Forgive thy neighbour the injury [done to thee], And then, while thou prayest, thy sins will be forgiven'). 'Lead me not into sin' appears in the 'morning blessings' of Jewish prayer.

8.Wilson and Sperber (2004) explain further that RT assumes, 'that the actual or expected relevance of two inputs can quite often be compared. These possibilities of comparison help individuals to allocate their cognitive resources, possibilities of comparison help individuals to allocate their cognitive resources, and communicators to predict and influs They also factors in experimental situations. As with other theories of comparable scope, its most general tenets can be tested only indirectly, by evaluating some of their consequences (Sperber \& Hirschfeld 2004:40-46).
} 
is that utterances encode logical forms which the speaker or writer has chosen to provide as input to the hearer's inferential comprehension process. Sub-tasks in the hearer's overall comprehension process include constructing an appropriate hypothesis about explicit content; constructing an appropriate hypothesis about the intended contextual assumptions, and also the intended implications. These subtasks are not sequentially ordered.

Wilson and Sperber observed that each person engaged in inferential communication with another arrives at the presumption of relevance, that is, the notion that (1) implicit messages are relevant enough to be worth bothering to process and (2) that the speaker will be as economical as they possibly can be in communicating it. The core of the theory is the 'communicative principle of relevance', which states that by the act of making an utterance the speaker is conveying that what they have said is worth listening to, that is, it will provide 'cognitive effects' worthy of the processing effort required to find the meaning (Wikipedia n.d.). The speaker must purposefully give the hearer a clue (ostensify), as to what he or she intends to communicate, so that the hearer can infer the intention both from the clue and the contextmediated information. The hearer then interprets the clue and surmises what the speaker intended to communicate. Thus, for relevance, in the first place the speaker or author must express intention, and the hearer must recognise it so that expectation is created. For the hearer to find the utterance relevant, the processing must yield positive cognitive effects, but the greater the processing effort required, the less relevant the input will be for the hearer.

Allot (2013) notes that in more recent work Wilson and Sperber (2004) argue that there is actually a mental module dedicated to utterance interpretation. It is now increasingly recognised that although the decoded logical form of an utterance is an important clue to the speaker's intentions, the explicitly communicated content of an utterance goes well beyond what is linguistically encoded. In addition to cognitive language, two other factors contribute to positive cognitive effects: emotive language and contextual implications. The subjective state of knowledge of a hearer when the hearer encounters an utterance also affects whether an input connects with background information that an individual has available to yield conclusions that matter to him or her. To see how powerfully extant background information influences the reception of an explicitly communicated content of an utterance see Figure 1.

The drawing in Figure 1 by a 6-year-old was done in response to the text of the booklet before illustrations were added. The drawing demonstrates that the child had already previously absorbed the idea that God is 'above', in the heavens, even though no mention is made of heaven in the booklet, and she conceives of God in anthropomorphic terms even though the booklet expressly speaks of God as a spirit. ${ }^{9}$

9.With respect to the accumulation of ideas already possessed the concept of 'apperceptive mass' is useful in explaining the complexity of the process of assimilation of new information. The 'apperceptive mass' of an individual is 'a group of present ideas, influential in determining what new ideas shall gain admission to of present ideas, influential in determining what new ideas shall gain admission to
consciousness and in what way new objects shall be perceived' (Corsini 2002:61). consciousness and in what way new objects
For example see Evans $(2010: 361-362$, n. 2).



Source: Drawing was given to the author by the child

FIGURE 1: Drawing by a 6-year-old child.

\section{The booklet}

Ernst-August Gutt recognised that since the search for optimal relevance undergirds all communication and that 'it is in the area of nonliteral language that Relevance Theory is perhaps the most powerful' (Pattemore 2007:257-258, quoting Gutt 1992:60). Gutt's prescription was kept in mind:

Translators should ... understand that there are important differences between expressing and implicating information, between strong and weak communication. They should understand the importance of open-endedness in communication $\ldots$ and the danger of limitation and distortion that can arise from explication. (Pattemore 2007:254-255)

For the trial the isiXhosa version was read by a parent figure to a group of five Xhosa-speaking young children ranging in age from 5-10 years, and the English version by a parent figure to two children aged six and ten. The parents were asked to allow the subjects to interrupt, comment or question during the reading. The reading process was recorded by video to provide a record of body language responses towards assessment of the degree of interest aroused by the reading (video recorded by author, with permission of parents and publication with permission of the parents). The text of the booklet presenting the Lucan version of the Lord's Prayer (Revised Standard Version [RSV]) is presented in italic script as it appears in consecutive pages in the booklet. The isiXhosa and Afrikaans versions are not given in this article. ${ }^{10}$ Comments are inserted for purposes of this article which were not in the original booklet.

Title page: I wonder ... how can we talk to God? Luke 11:2b-4.

Comment: The title page contains a statement of invitation to engage in an enquiry, according to the RT premise

10.The Xhosa and Afrikaans biblical texts are taken respectively from the following Bibles: Ibhayibhile Inguqulelo Entsha Egqityezelwe Ngowe-1996 (umbutho Webhayibhile: womzantsi-afrika) and Die Bybel vir Almal (originally 'Die Bybel vir Dowes', Bybelgenootskap van Suid-Afrika 2008) 
that utterances raise expectations of relevance. The value and importance of encouraging a sense of wonder, and wondering, has been dealt with in an earlier article (Evans forthcoming).

Page 1: How can we talk to God when we cannot even see God? In the Bible we read that God sent a very special person to teach us how we can talk to God. This person's name is Jesus. Some people said that Jesus is actually God's own child, and that God sent Jesus to teach us that God is like a loving father who wants to help us.

Comment: Here a brief introduction strengthens the stimulation of expectation, and preparation is made for the concept of God as father. The wording 'some people said ...' allows for future academic differences as a result of ongoing research and discussion in biblical scholarship, and stimulates an explorative attitude.

The reader spontaneously acts out the emotive content by gesturing that God loves and wants to help each one of the children. Figure 2 shows the seriousness with which the children receive and respond to the reading.

Page 2: When Jesus lived on earth he often prayed to God. His friends noticed that by talking to God he became wiser and happier. They wanted to be like him. So they asked him to teach them how to pray to God. This is what Jesus said we should say to God.

Comment: This is a statement of intention, so that expectation is elicited, together with an invitation to participate in what is to come.

\section{Page 3: [The first phrase]}

Father, Hallowed be your name.

God is our spiritual father who loves us and wants to help us. When we pray we respect God's name and praise God.

Comment: This explanation of the difficult word 'hallowed' is based on my understanding that God's name represents God's being, and is therefore holy, and is to be respected. This petition and the following, relates to God as father and to God's honour.



Source: Video recorded by author, with permission of parents and publication with permission of the parents

FIGURE 2: A father figure reads to children in an informal settlement.

\section{Page 4: [The second phrase]}

Your kingdom come

We want everybody to know that God is our best leader so that one day we will all do what God wants us to.

Comment: B $\alpha \sigma 1 \lambda \varepsilon 1 \alpha$ can mean reign or kingdom. This petition could also mean a collective state of being in which all of creation is completely under the control of God, and this is the sense which is intended to be conveyed on this page. To explain the first two difficult sentences of the prayer, one reader very helpfully added topical contextual information to explain the difficult concepts in the first and second sentences of the prayer: God is an even better leader than Tata Mandela!

Page 5: [The central phrase]

Give us each day our daily bread.

Every day we ask God to give us our food for the coming day so that we need not be anxious about the future.

Comment: In this version from the Gospel of Luke, the importance of this petition is signalled by being the central

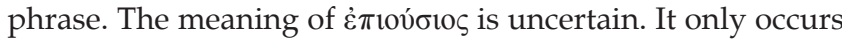
here and in Matthew's version of the Lord's Prayer, and is normally rendered as 'daily'. The word can also mean 'for tomorrow' (as noted in RSV and English Standard Version [ESV]). What can be more relevant to young children and their parents who experience anxiety about future nurturing? ${ }^{11}$ The video confirms particularly full engagement of the subjects at this stage.

Page 6: [The fourth phrase]

and forgive us our sins, for we ourselves forgive everyone who is indebted to us.

Forgive us when we do wrong or bad things, or do not do what we should, just as we forgive those who do us harm, or did not do for us what they should.

Comment: The results of a previous pilot study indicated that young children had little or no understanding of the concept 'sin' (Evans 2010:370). Postmodernism necessitates an alternative understanding of relation to creation than 'The Fall', but 'original sin' can still express meaningfully the sense of humanity's estrangement from God (Evans 2012: 84-86, 96). Linked to, and built upon the prior petition, this petition links our relationship to God with our relationship to one another. Here one of the readers spontaneously asked the children if they forgive their mother when she fails to do something for them that they want done. Their response showed that they fully engaged with the reader. The issue appeared to be particularly relevant to them. This finding confirms Rebecca Nye's definition of children's spirituality as 'relational consciousness' (Nye 1998:129-140).

11.The central petition for day-by-day sustenance would indeed be the most relevant content for a young child who is still geared to the satisfaction of his or her basic physical needs - consider the many child-headed households in South Africa. 'Poverty and the neglect and abandonment of children are realities that epitomize any "third-world" or underdeveloped society' (Sanchez-Cetina 2007:401). The any "third-world" or underdeveloped society' (Sanchez-Cetina 2007:401). The

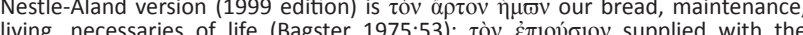

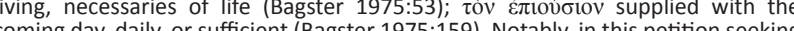
coming day, daily, or sufficient (Bagster 1975:159). Notably, in this petition seeking od's honour and kingdom comes before expression of dependence on God for physical sustenance. Kaplan (1979) states that we pray to remind ourselves of ou dependence upon God, and this makes one worthy of the good that God wants to give: 'Serve God your Lord, and He will bless your bread and your water' (Ex 23:25). 
Page 7: [The final phrase]

And lead us not into temptation.

Don't let us feel like doing bad things. Lead us in the way we should go.

Comment: The last phrase in Luke's version of the Lord's Prayer recognises that our own desires are not always trustworthy, and petitions God to keep us from falling short of the standard that God wants us to uphold. The prayer ends rather bluntly, so the explanation in the booklet repeats the petition in a positive form, and the illustrator has depicted a happy communal meal (Figure 3 ). ${ }^{12}$

\section{Assessment of results}

As far as assessment of results goes, an empirically plausible account of comprehension such as RT, can only be assessed qualitatively in terms of cognitive effects of the processing effort. In a previous pilot study it was found that some children became anxious by being questioned, even by their parents (Evans 2010:369). Therefore in this study, assessment of the effectiveness of the booklet was done solely through recording the body language and verbal responses of the subjects by video and asking the parents and isiXhosa translator (who subsequently viewed the videos) to assess to what extent the child experienced the content of the booklet as relevant. It was made clear to the parents that the assessment was a test for the design of the booklet, not a test of the children's ability.

\section{Discussion}

In this particular case the only assessment possible with young children as test subjects has been by means of interpretation of body language as observed in video recordings, feedback from parents and from the translator. To assess the research questions stated earlier, the parent figures, and the translator were interviewed after the trial. The feedback was positive. The booklet was approved, and the children were all responsive and understood the content. The translator who has spent a lifetime as a missionary in a Xhosa community assessed the video results carefully and thought that the children understood. He commented on the additional explanations given by the reader (father figure) as being excellent, but noted that the contextual pictures contributed largely to gain the children's interest and involvement.

\section{Conclusion}

This article has explored the possibility that a rational application of universally recognised relevance to a biblical text could go some way to, as it were, inoculate a child against future cognitive dissonance as they venture further into the postmodern world. The positive response suggests the possibility that early exposure in an open-ended way to a text such Luke 11:2-4 contains the possibility for future healthy negotiation in disputes. Sanchez-Cetina (2007:404) asks, how do we achieve 'Scripture engagement': 'How do receiving the good that God wishes to bestow upon us.

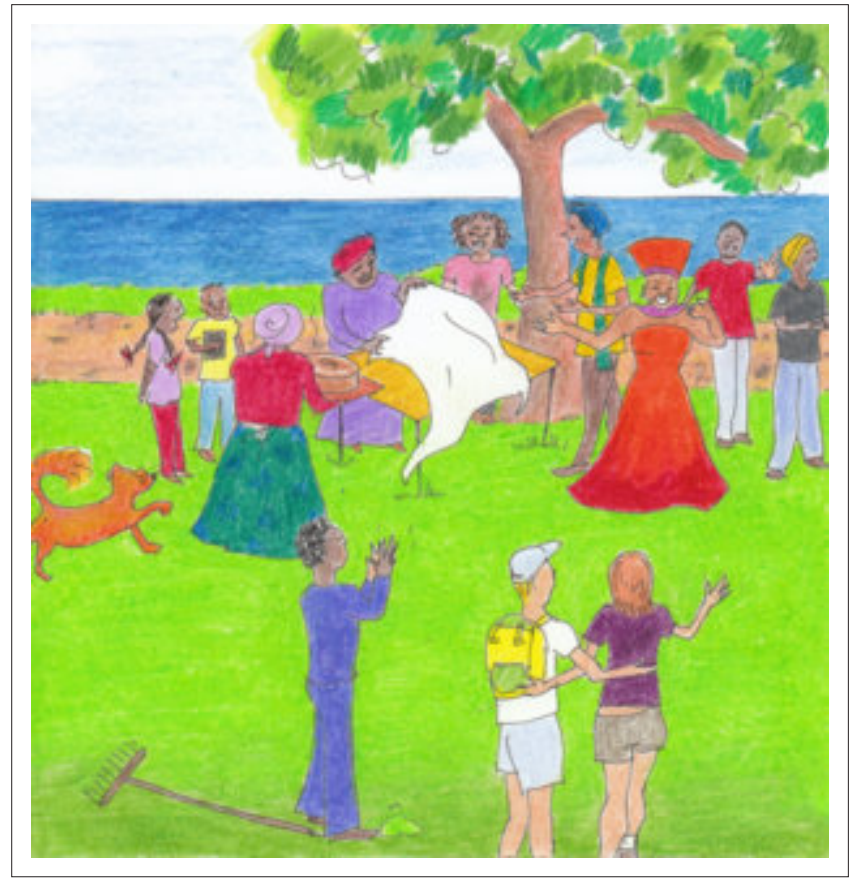

Source: Picture from booklet illustrated by Sarah Evans

FIGURE 3: People gather for a communal meal.

we make people "fall in love" with the Bible: read it, study it, and allow it to transform their lives?' It appears that if there are illustrations that to some extent reflect the child's own cultural context, and if there is an experience of sharing of enjoyment with a loving and caring adult, a young child's receptivity of a biblical text is facilitated. The actual contribution of the written text becomes blurred because the effect of the illustrations is inseparable from the textual context. The extent to which illustrations are essential to gain the interest of young children would depend on the liveliness and warmth of the relationship with the reader of the text. In this way for instance, the Xhosa oral tradition would compensate to some extent for a lack of illustrations.

The videos provide evidence of an often overlooked but very important aspect of young children's spirituality described by Rebecca Nye (1998): it is relational. I wonder if this relational quality is not perhaps the deciding factor that plants the seed of faith in young children? It may be that it is the promise of loving nurturance and trustworthy guidance that is relevant for a young child in Luke 11:2b-4, but perhaps at this age the biblical text is merely a vehicle for conveying care and leadership, but ultimately it is the sharing of a biblical text with a significant adult that makes the cognitive activity relevant and memorable. Hopefully the memory of such a pleasurable experience will encourage continued interest in the Bible in a postmodern world.

\section{Acknowledgements}

I would like to express appreciation to the translator, Ds Bennie Fourie and the illustrator Sarah Evans. Without them this research would not have been possible. 


\section{Competing interests}

The author declares that she has no financial or personal relationship(s) that may have inappropriately influenced her in writing this article.

\section{References}

Allot, N., 2013, 'Relevance Theory', viewed 22 June 2013, from http://www.Folk. uio.no/nicholea/papers/Draft_for_Allot,_N._(forthcoming)_Relevance_theory. in_A._Capone,

Astley, J., 1996, Christian theology and religious education: Connections and contradictions, Society for promoting Christian knowledge, Holy Trinity Church, Lontradictic.

Bagster, S., 1975, Analytical Greek Lexicon, Samuel Bagster \& Sons, London.

Bottigheimer, R.B., 1996, The Bible for Children: From the Age of Gutenberg to the Present, York University Press, New Haven/London.

Capone, A., Lo Piparo, F. \& Carapazza, M. (eds.), 2013, Perspectives on Pragmatics \& Philosophy, Springer, Berlin. http://dx.doi.org/10.1007/978-3-319-01011-3

Corsini, R.J., 2002, The Dictionary of Psychology, Brunner-Routledge, London.

Erickson, M., 1998, Postmodernising the Faith: Evangelical Responses to the Challenge of Postmodernism, Baker Books, Grand Rapids, MI.

Evans, A.H.M., Forthcoming, 'The Bible for children in a post-modern context: How do children form explanatory concepts?', Verbum et Ecclesia.

Evans, A.H.M., 2009, 'Explaining death to young children in a biblical context: A survey', Journal of Semitcs 18(2), 313-330.

Evans, A.H.M., 2010, 'A practical approach to methodological considerations in interpreting the Bible for children', Journal of Semitics 19(3), 361-375.

Evans, A.H.M., 2012, 'Evangelism of young children: Is an evolutionary understanding of "Original Sin" possible?', Old Testament Essays 25(1), 84-99.

Gold, P.S., 2004, Making the Bible Modern: Children's Bibles and Jewish education in twentieth-century America, Cornell University Press, Ithaca/London.

Gopnik, A., 2000, 'Explanation as orgasm and the drive for causal knowledge: The function, evolution and phenomenology of the Theory Formation System', in F.C. Keil \& R.A. Wilson (eds.), Explanation and cognition, pp. 299-323, The MIT Press, Cambridge, MA/London.

Gopnik, A., 2012, 'Scientific thinking in young children: Theoretical advances, empirical research, and policy implications', Science 28, September 337(6102), 1623-1627. http://dx.doi.org/10.1126/science.1223416
Gutt, E.-A., 1992, Relevance theory: A guide to successful communication in translation, Summer Institute for Linguistics, Dallas.

Harrison, V.S., 2007, Religion and Modern Thought, SCM Press, London.

Heilman, S., 1992, Defenders of the faith. Inside Ultra Orthodox Jewry, Schocken Books, New York.

Jones, T. \& Creasy-Dean, K., 2006, 'The Christianization of “Growing up" Global: Sowing hope in an ambivalent age', in R.R. Osmer \& K. Creasy- Dean (eds.), Youth, Religion \& Globalization and New Research in Practical Theology Internationa Practical Theology, vol. 3., pp. 251-272, Princeton Univertsity Press, Princeton.

Kaplan, A., 1979, The Handbook of Jewish Thought, vol. 2, Moznaim Publishing, New York.

Keil, F.C. \& Wilson, R.A. (eds.), 2000, Explanation \& Cognition, The MIT Press, Cambridge, MA/London.

Lansdown, R., 1995, 'Children's concept of an afterlife', Bereavement Care 16(2), 6-19.

Mitchell, B., 1996, 'Postscript: Conservation and criticism', in J. Astley \& L.J. Francis (eds.), Christian Theology and Religious Education. Connections and Contradictions, pp. 271-277, Society for Promoting Christian Knowledge, Holy Trinity Church, London.

Noss, P.A. (ed.), 2007, A history of Bible translation, Edizioni di Storia e Letteratura, Rome.

Nye, R., 1998, 'Psychological perspectives on children's spirituality', Doctoral dissertation, University of Nottingham, UK.

Osmer, R.R. \& Creasy, D.K. (eds.), 2006, Youth, religion \& globalization and new research in practical theology, vol. 3, International Practical Theology, Lit Verlag, Bern.

Pattemore, S., 2007, 'Framing Nida: The relevance of translation theory in the United Bible Societies', in P.A. Noss (ed.), A history of Bible translation, pp. 218-263, Edizioni di Storiae Letteratura, Rome.

Ratcliff, D. (ed.), 2004, Children's Spirituality: Christian perspectives, research, and applications, Cascade Books, Eugene, OR.

Sanchez-Cetina, E., 2007, 'Word of God, word of the people: Translating the Bible in post-missionary times', in P.A. Noss (ed.) A history of Bible translation, pp. 388408, Edizioni di Storia e Letteratura, Rome.

Sperber, D. \& Hirschfeld, L., 2004, 'The cognitive foundations of cultural stability and diversity', Trends in Cognitive Science 8, 40-46. http://dx.doi.org/10.1016/j. tics.2003.11.002

Wikipedia, n.d., s.v. 'Relevance theory', viewed 22 June 2013, from http://en.wikipedia. org/wiki/Relevance_theory?

Wilson, D. \& Sperber, D., 2004, 'Relevance Theory', in L.R. Horn \& G. Ward (eds.), The Handbook of Pragmatics, pp. 607-632, Blackwell, Oxford. 